\title{
Evaluating Land Use Effects on Groundwater Quality in Lagos-Nigeria Using Water Quality Index
}

\author{
I. I. Balogun ${ }^{1}$, I. S. Akoteyon ${ }^{2 *}$, and O. Adeaga ${ }^{1}$ \\ ${ }^{1}$ Department of Geography, University of Lagos, Akoka, Lagos, Nigeria \\ ${ }^{2}$ Department of Geography \& Planning, Lagos State University, Ojo, P.M.B, 1087, Apapa, Lagos, \\ Nigeria
}

Received 23 February 2011, accepted in final revised form 2 March 2012

\begin{abstract}
The study relates groundwater quality to land use types in Lagos State. Fourteen samples were collected from hand dug wells and boreholes, seven each from rural and urban land uses in the study area. Ten parameters $(\mathrm{pH}$, electrical conductivity, total dissolved solids, total hardness, calcium, magnesium, chloride, nitrate and sulfate) were determined using standard methods. The resulting water quality indices revealed that $58.09 \%$ of the samples were rated very poor while $21.73 \%, 9.08 \%$ and $11.1 \%$ were rated poor, good and excellent, respectively in rural land use. The analysis of samples drawn from urban land use revealed that $76.55 \%$ of the water was unfit for drinking while $14.4 \%, 6.42 \%$ and $2.63 \%$ were found to be very poor, good and excellent, respectively. $\mathrm{pH}$, total dissolved solids, chloride, total hardness and nitrate were beyond the permissible limits for urban land use while, $\mathrm{pH}$, total hardness and nitrate were above permissible limits for rural land use. These parameters were found to be responsible for the poor water quality rating in the study areas. The paper recommends a comprehensive effective sewerage system for safe disposal of sewage, efficient waste water handling and control of urban runoff to prevent groundwater quality deterioration in the study areas.
\end{abstract}

Keywords: Evaluation; Groundwater; Quality; Land use; Water quality index; LagosNigeria.

(c) 2012 JSR Publications. ISSN: 2070-0237 (Print); 2070-0245 (Online). All rights reserved.

doi: http://dx.doi.org/10.3329/jsr.v4i2.7142 J. Sci. Res. 4 (2), 397-409 (2012)

\section{Introduction}

The potential and quality of groundwater, is an economic resource and essential component of human life. However, the deterioration in major cities and urban centers due to population explosion, urbanization and industrialization results in large volume of effluent discharge that may affect the groundwater quality since the effluent from discharges or run-off from solid waste disposal sites generally moves vertically downwards [1-3].

\footnotetext{
*Corresponding author: sewwyco@yahoo.com
} 
Land use in geographic areas that replenish groundwater and surface water resources is increasingly recognized as an important factor affecting water quality and, consequently, the health of human and ecological communities sustained by these resources [4]. For instance, releases from commercial/industrial facilities, agricultural runoff and wastewater leaching into groundwater from residential septic systems can introduce a variety of pesticides into water supplies [5, 6]. Also, factors within land use settings affect the quality of ground water. For example, in areas not serviced by municipal sewers, age and density of septic systems affect ground water quality [7, 8].

The formulation and use of indices has been strongly advocated by agencies responsible for water supply and control of water pollution. Water quality index (WQI) is defined as a rating reflecting the composite influence of different water quality parameters [1]. The index serves as a tool for assessing the suitability of water quality. It also helps to harmonize complex water quality data into information that is understandable and usable by the public [9]. Thus, it becomes an important parameter for the assessment and management of groundwater. WQI is calculated from the point of view of the suitability of groundwater for human consumption.

In Lagos state, groundwater is vulnerable to various types of land uses. However, the extent of groundwater pollution depends on the rainfall pattern, depth of water table distance from the source of contamination and soil properties like permeability, composition of its recharge components as well as geology and hydrology of the area [10]. Concerns about potential exposure to these contaminants, primarily via water consumption and domestic uses, have provoked numerous studies to elucidate associations between specific health implications and chemical constituents in drinking water from land use-impacted water supplies.

The present study relates to the application of WQI for the study area on the experimental results of physico-chemical analysis of water samples from rural and urban land uses.

\section{Study Area}

Groundwater constitutes the major source of drinking and domestic uses of water in Lagos state. Two major seasons can be recognized in the state (dry season - November to March) and (wet season - April to October). Average temperature is about $27^{\circ} \mathrm{C}$ with annual average rainfall of about $1532 \mathrm{~mm}$ [11].

The drainage system is characterized by a maze of Lagoons and waterways which constitute about 22\% the state's total landmass. The area is drained by River Ogun in the centre, River Osun the east and River Yewa in the west, a sub-basin of Ogun-Osun River Basin.

The geology falls under the Benin formation and consists of highly porous sands and gravels with thin shale/clay inter-beds [12]. Groundwater flow shows a general North to South direction with two small cones of depression in Apapa and Ikeja due to intense groundwater abstraction [13]. Salinity level in the aquifer changes from north to south. In 
the northern and central parts of the state is fresh water-bearing aquifer. Salt water-bearing aquifer occurs in the southern coastal part of the state $[12,13]$.

The hydrogeology of the study area falls within the Dahomey sedimentary basin. It is made up of unfossiliferous sandstones and gravels weathered from underlying Precambrian basement rock [14]. The Dahomey Basin is bounded on the West by faults and tectonic structures while its eastern limit is marked by Benin hinge line. The aquifer within the Dahomey sedimentary basin extends almost from Accra in Ghana, through the Republic of Togo and Benin to Nigeria [14]. The Dahomey Basin consists of the Abeokuta group, Ewekoro formation, Coastal Plain Sands (CPS) and Recent sediments. The CPS is the most productive and most exploited aquifer in Lagos state. The Coastal Plain Sand aquifer is categorized into four types. The first aquifer comprises recent sediments while the second and third are the Upper and Lower Coastal Plains Sands aquifers, respectively. The fourth aquifer is the Abeokuta Formation [14]. The Upper Coastal Plain Sands (UCPS) aquifer has a water table whose depth ranges between 0.4 and $21 \mathrm{~m}$ below ground level with annual fluctuation of less than $5 \mathrm{~m}$ [15]. Water in this aquifer is usually tapped through hand dug wells and it is prone to pollution due to its nearness to the ground surface. The Lower Coastal Plain Sands (LCPC) aquifer, however, is tapped through boreholes and serves as the basis for the establishment of mini-water works in Lagos State [14, 16].

Badagry Local Government Area (LGA) is located approximately on latitude $7^{0} 15^{\prime} \mathrm{N}$ and $7^{0} 0^{\prime} \mathrm{N}$; longitude $5^{0} 0^{\prime} \mathrm{W}$ and $7^{0} 0^{\prime} \mathrm{W}$. It is bounded in the east by Ologe lagoon, north by Ogun state, in the south by Atlantic Ocean and in the west by Benin republic. The vegetation is characterized by marshy terrain in areas close to the lagoon while towards the eastern end is mangrove forest with some few grassland area [11].

Due to its rural nature a few areas are provided with pipe-borne water (Badagry township) while other communities lack access to pipe borne water. The major sources of water supply are shallow wells and water vendors. The quality of water supplied by water vendors cannot be guaranteed. Major human activities in the area include farming, fishing, trading among others [11].

Unlike Amuwo-Odofin, it is located approximately on latitudes $6^{0} 29^{\prime} \mathrm{N}$ and $6^{0} 27^{\prime} \mathrm{N}$; longitudes $3^{0} 14^{\prime} \mathrm{W}$ and $3012^{\prime} \mathrm{W}$. It is bounded by Ajeromi/Ifelodun LGA in the East, Isolo to the North, the Badagry Creek to the South and Ojo Local Government (LG) in the West. The LGA occupy about $134.6 \mathrm{~km}^{2}$ area. Its population is about 318.166 [17]. The vegetation types are marsh and swamp forest [18]. The major activities in the area includes commercial and industrial.

\section{Materials and Methods}

A total of 14 groundwater samples were collected from hand dug wells and boreholes in Badagry and Amuwo-Odofin LGAs, seven each from rural and urban land uses. Ten chemical parameters namely, $\mathrm{pH}$, electrical conductivity and Total dissolved solids, total 
hardness, calcium, magnesium, chloride, nitrate and sulfate were determined using standard methods for examination of water samples quality [19].

The co-ordinates of the sampling points were recorded using Global positioning system (GPS) Garmin Channel 72 model and were mapped using ArcGIS 9.3 (Fig. 1).

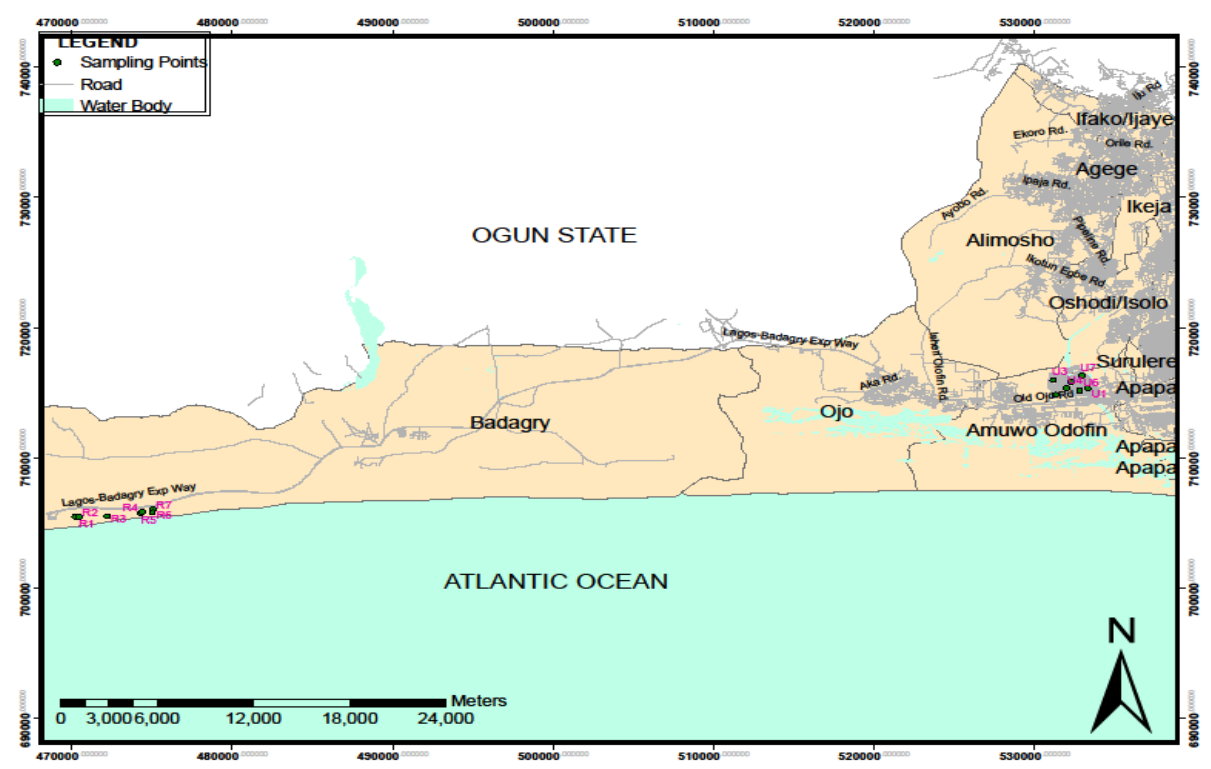

Fig. 1. Sampling location.

Samples were collected in clean 1.5 litre plastic jars with screw caps and labelled with appropriate codes $\left(\mathrm{R}_{1}-\mathrm{R}_{7}\right.$ and $\left.\mathrm{U}_{1}-\mathrm{U}_{7}\right)$ indicating rural and urban land uses, respectively. The sampled water were packed in a cooler containing ice and transported to the laboratory within 24hours from the time of sampling.

The in situ parameters, $\mathrm{pH}$, electrical conductivity and total dissolved solids were measured using potable digital meter, EXTECH pH-100 and HM digital EC/TDS/Temperature COM-100. Total hardness, calcium and chloride were determined using titrimetry method. Nitrate and sulfate were determined using HACH DR/2000 direct reading spectrophotometer. Total solids and magnesium were determined by gravimetry and Atomic absorption spectrophotometer (AAS), respectively.

The water quality index proposed by [20] was adopted to determine the suitability of the water for human consumption. The computation involved 3 steps. In the first step, 9 parameters were assigned suitable weights $\left(w_{i}\right)$ according to their relative importance in the overall quality of water for drinking/domestic purposes (Table 1). The assigned weights were based on well-formulated techniques of opinion-gathering to minimize subjectivity and enhance credibility [21]. 
Table 1 . Water quality parameters, their assigned weight and calculated relative weight.

\begin{tabular}{llll}
\hline Parameter & $\begin{array}{l}\text { Weight } \\
\left(w_{i}\right)\end{array}$ & $\begin{array}{l}\text { Relative Weight } \\
\left(W_{i}\right)\end{array}$ & $\begin{array}{l}\text { WHO standard (max } \\
\text { limit) for drinking water } \\
\text { quality [22] }\end{array}$ \\
\hline $\mathrm{pH}$ & 4 & 0.1333 & 8.5 \\
$\begin{array}{l}\text { Total dissolved solid } \\
(\mathrm{mg} / \mathrm{L})\end{array}$ & 4 & 0.1333 & 500 \\
$\begin{array}{l}\text { Total solid (mg/L) } \\
\text { Chloride (mg/L) }\end{array}$ & 4 & 0.1333 & 2000 \\
Calcium (mg/L) & 2 & 0.1000 & 200 \\
Magnesium (mg/L) & 2 & 0.0667 & 75 \\
$\begin{array}{l}\text { Total hardness } \\
(\mathrm{mg} / \mathrm{L})\end{array}$ & 2 & 0.0667 & 150 \\
Nitrate (mg/L) & 5 & 0.0667 & 30 \\
Sulfate (mg/L) & 4 & 0.1333 & 5 \\
Total & $\sum w_{\mathrm{i}}=30$ & $\sum W_{i}=1.000$ & \\
\hline
\end{tabular}

In the second step, the relative weight $\left(W_{\mathrm{i}}\right)$ was computed based on the equation:

$$
W_{i}=\frac{w_{i}}{\sum_{i=1}^{n} w_{i}}
$$

where, $W_{\mathrm{i}}$ is the relative weight, $w_{\mathrm{i}}$ is the weight of each parameter and $\mathrm{n}$ is the number of parameters.

In the third step, a quality rating scale $\left(q_{i}\right)$ for each parameter was determined by dividing the concentration of each water parameter by its respective standard according to the guidelines by WHO [22] and the result was multiplied by 100 based on the equation

$$
q_{i}=c_{i} / s_{i} \times 100
$$

' $q_{i}$ ' is the quality rating for water quality parameter ' $i$ ' in water sample, ' $c_{i}$ ' is the concentration of water quality parameter ' $i$ ' in water sample, and ' $s_{i}$ ' is the standard (max. limit) for water quality parameter ' $i$ ' recommended by WHO.

To compute the WQI, the SI was determined first, for each water parameter as per the following equations:

$$
\begin{gathered}
S I_{i}=W_{i} \cdot q_{i} \\
W Q I=\sum S I_{i}
\end{gathered}
$$


where (SI) is the sub-index, $S I_{i}$ is the sub-index of $i$ th parameter and $q_{\mathrm{i}}$ is the rating based on concentration of ith parameter and $n$ is the number of parameters.

The computed WQI values were categorized into five types, "excellent water" to “water, unsuitable for drinking” according to Brown et al. [20] (see Table 2).

Table 2. Categorization of water quality index.

\begin{tabular}{cccc}
\hline \multirow{2}{*}{$\begin{array}{c}\text { Water quality } \\
\text { index }\end{array}$} & Description & \multicolumn{2}{c}{$\begin{array}{c}\text { Percentage of water } \\
\text { sample }\end{array}$} \\
\cline { 3 - 4 } & & Rural & Urban \\
\hline $0-25$ & Excellent & 11.10 & 2.63 \\
$26-50$ & Good & 9.08 & 6.42 \\
$51-75$ & Poor & 21.73 & nil \\
$76-100$ & Very poor & 58.09 & 14.40 \\
$>100$ & Unfit for drinking (UFD) & nil & 76.55 \\
\hline
\end{tabular}

Source: Brown et al. [20].

\section{Results and Discussion}

The measured depths of the sampled wells under rural and urban land uses are presented in Table 3.

Table 3. Depths of sampled wells.

\begin{tabular}{llll}
\hline Sample code & Depth (m) & Sample code & Depth (m) \\
\hline R1 & 3.1 & $\mathrm{U} 1$ & 27 \\
R2 & 3.3 & $\mathrm{U} 2$ & 35 \\
R3 & 2.8 & $\mathrm{U} 3$ & 45 \\
R4 & 3.1 & $\mathrm{U} 4$ & 35 \\
R5 & 2.25 & $\mathrm{U} 5$ & 55 \\
R6 & 2.8 & $\mathrm{U} 6$ & 64 \\
R7 & 3.6 & $\mathrm{U} 7$ & 30 \\
Mean & 2.99 & Mean & 41.57 \\
\hline
\end{tabular}

$\mathrm{R}=$ Rural, $\mathrm{U}=$ Urban.

The mean depths of the sampled hand dug wells are $2.99 \mathrm{~m}$ in rural land use and 41.57 $\mathrm{m}$ for boreholes in urban land use. Depth of sampling in wells was narrow in range being between 2.25 and $3.6 \mathrm{~m}$ in rural land use while it was wider in urban land use; between 27 and $64 \mathrm{~m}$. 
The descriptive statistics of groundwater quality in rural land use is presented in Table 4. The result shows that $\mathrm{pH}$ ranges between 6.2 and 7.3 with a mean of 6.67 , indicating a slightly acidic condition [23].

Electrical conductivity ranges between 101 and $293 \mu \mathrm{S} / \mathrm{cm}$ with a mean of $172.57 \mu \mathrm{S} / \mathrm{cm}$. TDS is between 54 and $148 \mathrm{mg} / \mathrm{l}$ with a mean of $88.71 \mathrm{mg} / \mathrm{l}$. TDS, Cl, Ca, $\mathrm{Mg}, \mathrm{TH}, \mathrm{NO}_{3}$ and $\mathrm{SO}_{4}$ range between 54 and 149mg/l, 24 and $38 \mathrm{mg} / \mathrm{l}, 22$ and $80 \mathrm{mg} / \mathrm{l}, 2$ and 34mg/l, 38 and $114 \mathrm{mg} / \mathrm{l}, 1.49$ and $18.24 \mathrm{mg} / \mathrm{l}$, and 3 and 32mg/l, respectively. Corresponding mean values are 91.71, 31.14, 49.14, 13.43, 62.29, 4.23 and $8.71 \mathrm{mg} / \mathrm{l}$, respectively.

According to [24] groundwater quality based on chloride can be classified as fresh while, groundwater quality based on total hardness is classified as moderately hard [23]. On the pattern of relative variation, the results of the coefficient of variation (C.V) show that all the examined variables in rural land use with the exception of $\mathrm{pH}, \mathrm{EC}$, TDS, TS, $\mathrm{Cl}, \mathrm{Ca}$, and $\mathrm{TH}$ are heterogeneous. $\mathrm{NO}_{3}$ for example tops the list with a value of $143.34 \%$.

Table 4. Descriptive statistics of groundwater quality in rural land use.

\begin{tabular}{lllll}
\hline Parameter & Min & Max & Mean & C.V (\%) \\
\hline $\mathrm{pH}$ & 6.2 & 7.3 & 6.67 & 5.39 \\
$\mathrm{EC}(\mu \mathrm{S} / \mathrm{cm})$ & 101 & 293 & 172.57 & 41.57 \\
$\mathrm{TDS}(\mathrm{mg} / \mathrm{l})$ & 54 & 148 & 88.71 & 39.56 \\
$\mathrm{TS}(\mathrm{mg} / \mathrm{l})$ & 54 & 149 & 91.71 & 38.07 \\
$\mathrm{Cl}(\mathrm{mg} / \mathrm{l})$ & 24 & 38 & 31.14 & 19.91 \\
$\mathrm{Ca}(\mathrm{mg} / \mathrm{l})$ & 22 & 80 & 49.14 & 40.48 \\
$\mathrm{Mg}(\mathrm{mg} / \mathrm{l})$ & 2 & 34 & 13.43 & 81.46 \\
$\mathrm{TH}(\mathrm{mg} / \mathrm{l})$ & 38 & 114 & 62.29 & 40.54 \\
$\mathrm{NO}_{3}(\mathrm{mg} / \mathrm{l})$ & 1.49 & 18.24 & 4.23 & 143.34 \\
$\mathrm{SO}_{4}(\mathrm{mg} / \mathrm{l})$ & 3 & 32 & 8.71 & 118.94 \\
\hline
\end{tabular}

Min $=$ minimum, $\max =$ maximum, $\mathrm{C} . \mathrm{V}=$ coefficient of variation .

The descriptive statistics of groundwater quality in urban land use is presented in Table 5. The result shows that $\mathrm{pH}$ ranges between 8.1 and 8.9 with a mean of pH8.46 while EC is from 39.4 to $3,010 \mu \mathrm{S} / \mathrm{cm}$ with a mean of $1,305 \mu \mathrm{S} / \mathrm{cm}$. TDS is between 21 and $1,410 \mathrm{mg} / \mathrm{l}$ with a mean of $614.86 \mathrm{mg} / \mathrm{l}$. TS, $\mathrm{Cl}, \mathrm{Ca}, \mathrm{Mg}, \mathrm{TH}, \mathrm{NO}_{3}$ and $\mathrm{SO}_{4}$ ranged between 21 and 1,410mg/l, 14 and 1,300mg/l, 0 and 514mg/l, 14 and 624mg/l, 1.5 and 54mg/l, and 1 and 36mg/l, respectively. Corresponding mean values are 616.43, 285.43, 60.71, 135.86, 196.57, 23.14 and $15.43 \mathrm{mg} / \mathrm{l}$, respectively. The $\mathrm{pH}$ of the groundwater indicates a moderately alkaline condition, according to the classification system of [23]. Electrical Conductivity is an indicator of the amount of material dissolved in water while Total 
Dissolved Solids is a measure of the total amount of minerals dissolved in water. The latter is a very useful parameter in the evaluation of water quality [23].

Calcium and Magnesium are constituents of hard water. They are the most abundant cationic constituent of natural water. Its content in natural water depends on the geological source and chemical weathering process. TDS in groundwater though generally not harmful to humans, however, high concentrations may affect persons suffering from kidney and heart diseases [25].Water containing high total solids may also cause laxative or constipation effects.

On the pattern of relative variation, the results of the coefficient of variation show that all the examined variables in urban land use with the exception of $\mathrm{pH}$, are heterogeneous. Chloride for example tops the list with a value of $162.37 \%$. Considering the high variability of groundwater quality parameters in the urban land uses, therefore, there is a need for routine monitoring and thorough boiling of water before consumption.

Table 5. Descriptive statistics of groundwater quality in urban land use.

\begin{tabular}{lllll}
\hline Parameter & Min & Max & Mean & C.V (\%) \\
\hline pH & 8.1 & 8.9 & 8.46 & 3.43 \\
EC $(\mu \mathrm{S} / \mathrm{cm})$ & 39.4 & 3010 & 1305.77 & 82.91 \\
TDS (mg/l) & 21 & 1410 & 614.86 & 81.97 \\
TS (mg/l) & 21 & 1410 & 616.43 & 81.81 \\
$\mathrm{Cl}(\mathrm{mg} / \mathrm{l})$ & 14 & 1300 & 285.43 & 162.37 \\
$\mathrm{Ca}(\mathrm{mg} / \mathrm{l})$ & 4 & 148 & 60.71 & 88.24 \\
$\mathrm{Mg}(\mathrm{mg} / \mathrm{l})$ & 0 & 514 & 135.86 & 140.31 \\
$\mathrm{TH}(\mathrm{mg} / \mathrm{l})$ & 14 & 624 & 196.57 & 117.81 \\
$\mathrm{NO}_{3}(\mathrm{mg} / \mathrm{l})$ & 1.5 & 54 & 23.14 & 69.79 \\
$\mathrm{SO}_{4}(\mathrm{mg} / \mathrm{l})$ & 1 & 36 & 15.43 & 69.79 \\
\hline
\end{tabular}

An assessment of the quality of the groundwater sampled using the WHO standards was done. Mean values of the sampled wells in rural land use shows that, TDS and $\mathrm{SO}_{4}$ concentration were within the WHO limit of $500 \mathrm{mg} / \mathrm{L}$ while in urban land use, mean concentration of TDS $(614.86 \mathrm{mg} / \mathrm{L})$ exceeds the WHO limit for drinking water. High concentration of sulfate along with magnesium in drinking water can lead to gastrointestinal irritation and respiratory illness [26].

Total solids and electrical conductivity of the sampled wells under rural land use were found to be within the prescribed WHO limit of $2000 \mathrm{mg} / \mathrm{L}$ and $1000 \mu \mathrm{S} / \mathrm{cm}$, respectively, for drinking water. Electrical Conductivity of water is directly related to the concentration of ions and their mobility. Studies show that EC is indicative of dissolved ionizable solids 
[27]. The results also show that $\mathrm{pH}$ exceeded the WHO standard at locations $\mathrm{Ug}_{3}$, Ug6 and $\mathrm{Ug}_{7}$ in urban land use. Similarly, EC and TDS exceeded the WHO standards at locations $\mathrm{Ug}_{1}, \mathrm{Ug} 2 \& \mathrm{Ug}_{5}$ in urban land use. In all the sampling locations, TS was found to be within the WHO standard limit for drinking water quality (Fig. 2).

The high concentration of EC and TDS in urban land use can be attributed to urban runoff and pollutants resulting from human activities that infiltrate into the sub-surface or runoff into the nearby stream [28].

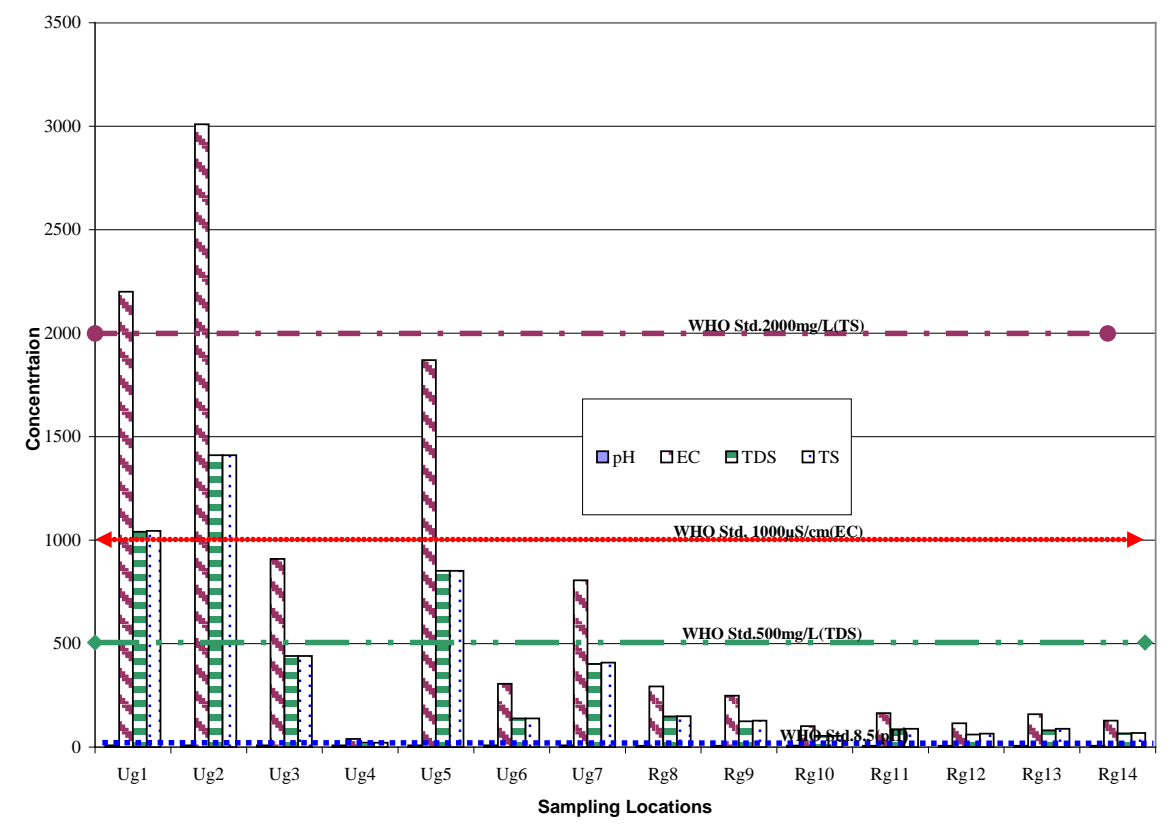

Fig. 2. Variation of pH, EC, TDS and TS with WHO standard in urban and rural land uses.

Fig. 3 shows the variation of groundwater parameters $\left(\mathrm{Cl}, \mathrm{Ca}, \mathrm{Mg}, \mathrm{TH}, \mathrm{NO}_{3}\right.$ and $\mathrm{SO}_{4}$ ) with WHO standard in urban and rural land uses. Chloride was found to be within the WHO standard limit for drinking water quality in urban and rural land uses except at locations $\mathrm{Ug}_{1}, \mathrm{Ug}_{2}$ and $\mathrm{Ug}_{5}$. Calcium exceeded WHO standard in all the sampling locations, except at locations $\mathrm{Ug}_{4}, \mathrm{Ug}_{6}, \mathrm{Rg}_{10}$ and $\mathrm{Rg}_{12}$ to $\mathrm{R}_{14}$.

High concentration of Ca may be due to the discharge of industrial wastes and passage through deposits of limestone, dolomite, and gypsum [29]. Water containing high calcium is not suitable for washing, bathing and in boilers and is linked to the formation of concretion in the body and may cause gastro intestinal diseases and stone formations.

In all the sampling locations, Mg was found to be within the WHO limit for drinking water except at locations $\mathrm{Ug}_{1}, \mathrm{Ug}_{7}$ in urban land use. Total Hardness exceeded the WHO limit in all the sampling locations except at locations $\mathrm{Ug}_{3}, \mathrm{Ug}_{4} . \mathrm{NO}_{3}$ exceeded the WHO 
limit in all the sampling locations except at locations $\mathrm{Rg}_{9}-\mathrm{Rg}_{14}$. High level of $\mathrm{NO}_{3}$ in groundwater can be attributed to seepage from dilapidated septic tanks in residential area or from runoff from agricultural land [30]. They also contribute to high level of chloride, Dissolved solids, sodium, calcium, and potassium to shallow wells [31]. Excess of $\mathrm{NO}_{3}$ is responsible for methemoglobinemia in infants and also causes physiological distress and bitter taste, among others [23]. Sulfate is the chemical constituent of all natural waters and may result from the chemical weathering of geological formations or biologically mediated oxidation of reduced sulfur species [32]. $\mathrm{SO}_{4}$ was found to be within the WHO limit for drinking water in all the sampling locations (Fig. 3).

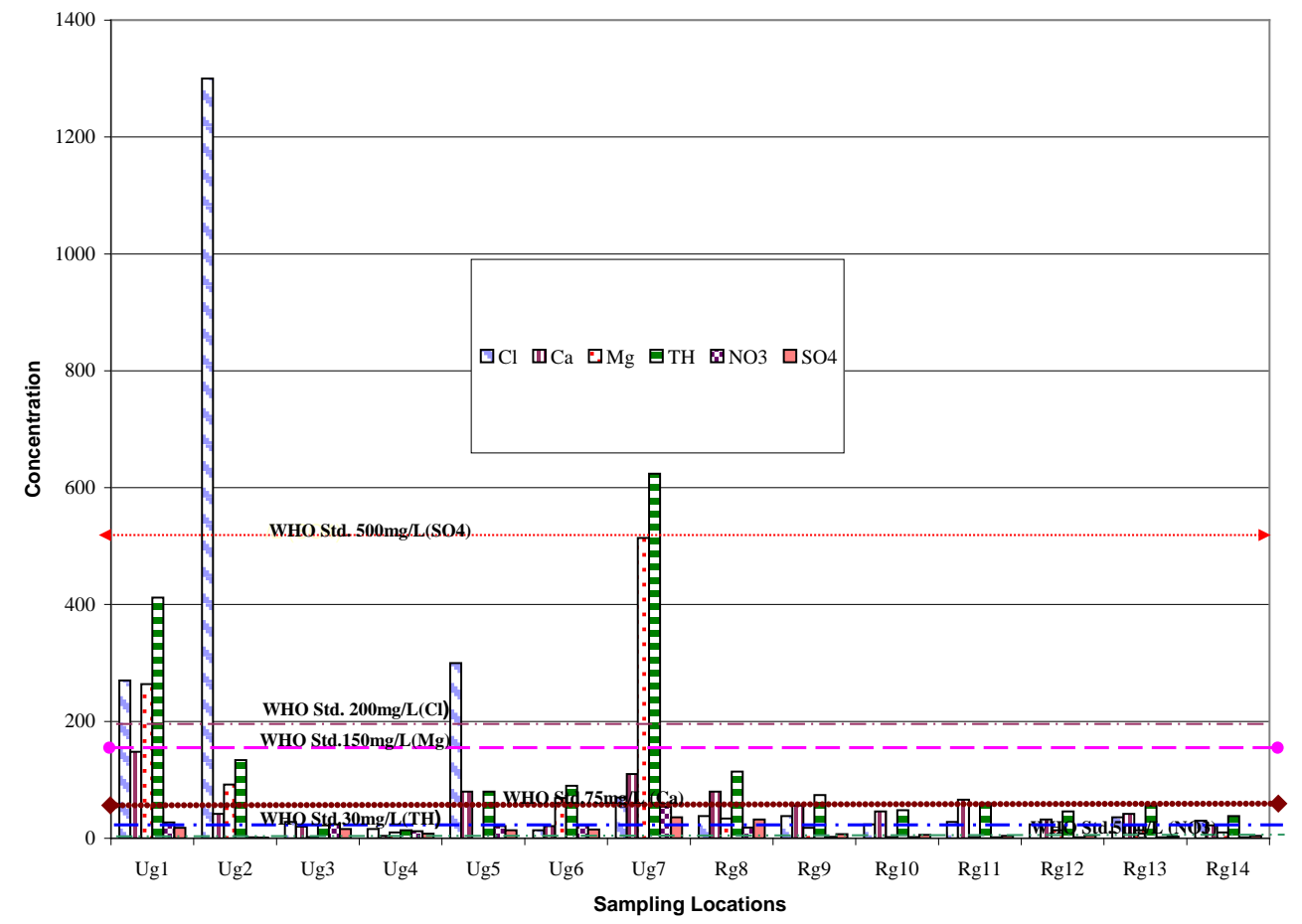

Fig. 3. Variation of $\mathrm{Cl}, \mathrm{Ca}, \mathrm{Mg}, \mathrm{TH}, \mathrm{NO}_{3}$ and $\mathrm{SO}_{4}$ with $\mathrm{WHO}$ standard in urban and rural land uses.

Tables 6 and 7 present the calculated WQI of the sampled wells under rural and urban land uses. Water quality index is calculated to determine the suitability of water for drinking purpose [33, 34]. The computed WQI in rural and urban land uses show that the WQI ranges from 1.63 to 98.86 and 2.88 to 540.11 , respectively for the land uses.

Table 6 shows that, under the rural land use, the classes of WQI indicate that $58.09 \%$ of the sampled water was very poor while $21.73 \%, 9.08 \%$ and $11.1 \%$ were rated poor, good and excellent water, respectively. Three groundwater parameters $\left(\mathrm{pH}, \mathrm{TH}\right.$ and $\left.\mathrm{NO}_{3}\right)$ 
of the sampled wells under rural land use made the water to be rated poor. Their levels thus render groundwater resource unsuitable for human consumption (Table 6).

Table 6. Calculated water quality index of sampled wells under rural land use.

\begin{tabular}{llllllllll}
\hline SC & $\mathrm{pH}$ & $\mathrm{TDS}$ & $\mathrm{TS}$ & $\mathrm{Cl}$ & $\mathrm{Ca}$ & $\mathrm{Mg}$ & $\mathrm{TH}$ & $\mathrm{NO}_{3}$ & $\mathrm{SO}_{4}$ \\
\hline Rg1 & 10.04 & 3.95 & 0.99 & 1.9 & 7.11 & 1.51 & 25.35 & 60.81 & 0.85 \\
Rg2 & 9.72 & 3.33 & 0.85 & 1.9 & 4.98 & 0.08 & 16.45 & 8.54 & 0.19 \\
Rg3 & 11.45 & 1.44 & 0.36 & 1.2 & 4.09 & 0.09 & 10.67 & 7.3 & 0.16 \\
Rg4 & 10.82 & 2.29 & 0.59 & 1.4 & 5.87 & 0.09 & 13.34 & 5.07 & 0.11 \\
Rg5 & 10.51 & 2.29 & 0.43 & 1.2 & 2.85 & 0.62 & 10.23 & 6.2 & 0.13 \\
Rg6 & 10.51 & 2.16 & 0.59 & 1.8 & 3.74 & 0.62 & 12.45 & 4.97 & 0.08 \\
Rg7 & 10.19 & 1.76 & 0.45 & 1.5 & 1.96 & 0.44 & 8.45 & 5.97 & 0.11 \\
WQI & 73.24 & 17.22 & 4.26 & 10.9 & 30.6 & 3.45 & 96.94 & 98.86 & 1.63 \\
\%WS & 21.73 & 5.11 & 1.26 & 3.23 & 9.08 & 1.02 & 28.76 & 29.33 & 0.48 \\
WQR & Poor & Excellent & Excellent & Excellent & Good & Excellent & Very poor & Very poor Excellent \\
\hline
\end{tabular}

SC - Sampling code, Rg - Rural groundwater, WQI - Water quality Index, WS - Water sample, WQR - Water quality rating,

Table 7. Calculated water quality index of sampled wells under urban land use.

\begin{tabular}{llllllllll}
\hline SC & pH & TDS & TS & Cl & Ca & Mg & TH & $\mathrm{NO}_{3}$ & $\mathrm{SO}_{4}$ \\
\hline Ug1 & 12.86 & 27.73 & 6.96 & 13.5 & 13.16 & 11.74 & 91.6 & 90.02 & 0.48 \\
Ug2 & 12.7 & 37.59 & 9.39 & 65 & 3.74 & 4.09 & 29.79 & 5 & 0.03 \\
Ug3 & 13.64 & 11.73 & 2.93 & 1.4 & 1.78 & 0.09 & 4.89 & 80.02 & 0.43 \\
Ug4 & 13.33 & 0.56 & 1.05 & 0.8 & 0.36 & 0.44 & 3.11 & 40 & 0.21 \\
Ug5 & 12.86 & 14.32 & 5.68 & 1.5 & 7.11 & 0 & 17.79 & 70.01 & 0.37 \\
Ug6 & 13.96 & 3.71 & 0.93 & 0.7 & 1.87 & 3.07 & 20.01 & 75.02 & 0.4 \\
Ug7 & 13.49 & 10.72 & 2.72 & 3.5 & 9.78 & 22.86 & 138.74 & 180.04 & 0.96 \\
WQI & 92.84 & 106.36 & 29.66 & 86.4 & 37.8 & 42.29 & 305.93 & 540.11 & 2.88 \\
\% WS & 7.46 & 8.55 & 2.4 & 6.94 & 3.03 & 3.39 & 24.59 & 43.41 & 0.23 \\
WQR & Very Poor UFD & Excellent & Very poor Good & Good & UFD & UFD & Excellent \\
\hline
\end{tabular}

Ug - Urban groundwater; UFD - Unfit for drinking.

Table 7 also shows that, under urban land use, $76.55 \%$ of the sampled water was unfit for drinking while $14.4 \%, 6.42 \%$ and $2.63 \%$ were very poor, good and excellent water, respectively. Also the WQI rating suggests that $55 \%$ of the parameters $(\mathrm{pH}, \mathrm{TDS}, \mathrm{Cl}, \mathrm{TH}$ 
and $\mathrm{NO}_{3}$ ) rendered the water within sampled wells under urban land use unsuitable for human consumption (Table 7).

\section{Conclusion}

Based on the computed WQI of the two land use types, groundwater resource could be more susceptible to contamination in urban areas. The results indicate that certain parameters such as $\mathrm{pH}$, total dissolved solids, chloride, total hardness and nitrate did not meet the WHO limits for drinking water. The situation under rural land use suggests that only $\mathrm{pH}$, total hardness and nitrate parameters were beyond the permissible limits. Under both land uses, these parameters were found to be responsible for the poor water quality rating in the study areas. It is thus essential that an efficient, safe and effective sewerage system for disposal of sewage, wastes water and control of urban runoff should be developed to ameliorate ground water quality deterioration in the study areas.

\section{References}

1. C. R. Ramakrishnaiah, C. Sadashivaiah, and G. Ranganna, E. J. Chemistry 6 (2) 523 (2009).

2. R. K. Nageswara, L. P. Swarna, and K. P. V Ramesh, Indian J. Environ. Protec. 27 (11), 996, (2007).

3. V. S. Shrivastava and S. N. Vaishnav, Indian J. Environ. Protec. 22 (5), 559 (2002).

4. R. B. Levin, P. R. Epstein, T. E. Ford, W. Harrington, E. Olson, and E. G. Reichard, Environ. Health Perspect. 110 (1), 43 (2002). http://dx.doi.org/10.1289/ehp.02110s143 PMid:11834462 PMCid:1241146

5. D. A. V. Eckhardt and P. E .Stackelberg, Ground Water 33 (6), 1019 (1995). http://dx.doi.org/10.1111/j.1745-6584.1995.tb00047.x

6. D. W. Kolpin, E. T. Furlong, M. T. Meyer, E. M. Thurman, S. D .Zaugg, L. B .Barber, and H. T Buxton, Environ. Sci. Technol. 36 (6), 1202 (2002). http://dx.doi.org/10.1021/es011055j

7. M. V. Yates, Ground Water 23 (5), 586 (1995). http://dx.doi.org/10.1111/j.1745-6584.1985.tb01506.x

8. A. J .Gold, W. R. DeRagon, W. M .Sullivan, and J. L. Lemunyon, J. Soil Water Conserv. 45, 305 (1990).

9. S. S. Asadi, P. Vuppala, and M. A. Reddy, Indian Int. J. Environ. Res. Publ. Health 4 (1), 45, (2007). http://dx.doi.org/10.3390/ijerph2007010008 PMid:17431315

10. A .K. De, Environmental Chemistry, 3rd Ed. (Wiley Eastern Ltd., New Delhi, 1995).

11. T. Odumosu, Y. Balogun and K. Ojo, (Rex Charles Publication, Ibadan 1999) pp. 1-50.

12. A. U .Oteri and F. P. Atolagbe, Saltwater Intrusion into Coastal Aquifers in Nigeria, the 2nd Intl. Conf. on Saltwater Intrusion and Coastal Aquifers - Monitoring, Modeling, and Management. Mérida, Yucatán, México. (2003).

13. B. Coode, K. Rofe, and Lapworth Hydrogeological Investigation Report of Lagos State, 1 \& 2, (1997).

14. E. O. Longe, Res. J. Environ. Earth Sci. 3 (1), 1 (2011).

15. Y. A .Asiwaju-Bello, and O. S. Oladeji, Nigerian J. Mining and Geol. 37, 185 (2001).

16. A. A. Adepelumi, B. D. Ako, T. R. Ajayi, O. Afolabi, and E. J. Omotoso, Environ. Geol. 56 (5), 927 (2008). http://dx.doi.org/10.1007/s00254-008-1194-3

17. NPC, (National Population Census, Official Gazette Legal Notice on Publication of the details of breakdown of the National and State Provisional Totals, 2006).

18. A. I. Babatunde, I. M .Okolue, O. T .Oyelola, and A. K . Odunlade, Int. J. Pure App. Sci. 3 (2), 49 (2009). 
19. APHA, Standard methods for examination of water and wastewater (American Public Health Association New York, 1998).

20. R. M. Brown, N. I. McClelland, R. A. Deininger, and R. G. Tozer, J. Water and Sewage Works 117, 339 (1970).

21. S. A. Abbasi and D. S. Arya, Environmental Impact Assessment (Discovery Publishing House, New Delhi, 2000).

22. WHO (World Health Organization, Guidelines for Drinking Quality, $3^{\text {rd }}$ Ed. (Geneva, 2006).

23. D. K .Todd, and L.W. Mays, Groundwater Hydrology, 3rd Ed. (John Wiley and Sons, New York, 2005).

24. P. T. Stuyfzand, Int. Assoc. Hydrol. Sci. 184, 89 (1989).

25. S. K .Gupta and R. D. Deshpande, Current Science 86 (9), 1216 (2004).

26. A. G. Umadevi, M. George, P. Dharmalingam, P. A. Jose, M .Rajagopalan, B. Dhanya, P. P Haridasan, and P. M. B. Pillai, E. J. Chemistry 7 (3), 908 (2010).

27. S. Gupta, M. Bhatnagar, and R. Jain, Asian J. Chem. 15, 71 (2003).

28. B. L. Morris, A. R. Lawrence, P. J. Chilton, B. Adams, R. Calow, and B. A. Klinck, Groundwater and its susceptibility to degradation: a global assessment of the problem and options for management, Early Warning and Assessment Report Series, UNEP (United Nations Environment Programme), Nairobi, Kenya, Report RS 03-3: 126 p, (2003).

29. D. K. Todd, Ground Water Hydrology (John Wiley and Sons, New York, 1980).

30. P. J .Squillance and C. V. Price, Urban land use study plan for the national water quality assessment programme, USGS, open file report 96 (1996).

31. M. A .Thomas, J. American Water Resources Assoc. 36 (5), 1023 (2000). http://dx.doi.org/10.1111/j.1752-1688.2000.tb05707.x

32. NRC (National Research Council), Groundwater vulnerability assessment: contamination potential under conditions of uncertainty (National Academy Press, Washington, DC., 1993).

33. M. Das Gupta, K. M. Purohit, and D. Jayita, J. Environ. Pollu. 8, 285 (2001).

34. A. K. Srivastava and D. K. Sinha, Indian J. Environ. Prot. 14, 340 (1994). 